\title{
FOR THE SAKE OF A LIBERALIZED ROMANIAN CULTURE! WHAT ABOUT AN INTERDISCIPLINARY AND TRANSDISCIPLINARY CANON INSTEAD OF ISOLATED MONOPOLIES WITH A SUBSCRIPTION TO THE STATE BUDGET?
}

\author{
Felix NICOLAU \\ Lund University \\ e-mail: felixnicolau1@gmail.com
}

\begin{abstract}
Fake canonizations are prevalent in the former communist countries wherein arts and culture in general may still function as propaganda weaponry at the hands of the sponsoring state. The public is almost eliminated from the process of canonization, as the publishing houses, art galleries, and cultural industries seldom survive and flourish from sales to a real public. As a rule, their rarefied public is summoned from a flimsy contingent, from the less promoted artists who try thus to conjure the benevolence of the critics and famed authors/artists, and from those who are ready to attend cultural events as long as they are financially covered by the state. For instance, a sizable percent of the funds directed towards literature from the state budget in Romania has been constantly invested in the promotion of Mircea Cărtărescu in the vain hope (so far) the Romanian literature will be awarded the Nobel Prize for literature and will cure thus a profusely nourished complex of inferiority. Maybe in the new future. Meanwhile, many more modern and impactful writers simply vanish into the abyss of anonymity as the bookshops are interested in promoting only those writers coming from publishing houses with a subscription to the state budget. This would be one explanation for the constant decrease in the public paying for literary and artistic works. The result of an haphazard process of canonization and of the lack of a free cultural market (at least $50 \%$ of investments coming from private sources) are obvious. Wherefrom the impending need of an interdisciplinary and transdisciplinary super-arch-canon.
\end{abstract}

Keywords: canon; canonicity; interdisciplinarity; transdisciplinarity; posthumanism; Romanian literature;

"Without suggesting an exhaustion of the symbolic resources of the figurative model of the mirror, we find it significant to stop at Narcissus, the first famous man fascinated by the mirroring of his own face, because his myth is the subject of a particularly long-living symbolism, but not less processual. Promoted in antiquity as quite a tragic, the young man punished by Nemesis for the pride of being self-sufficient and to have refused love, so 
the relationship, in time, will become, successively, a figure of selfreflexivity and, finally, of the amended ostentation." (Mihaela Ursa. The Eighties and the Promises of Postmodernism, 1999: 39 - Translations are mine, unless stated otherwise) ${ }^{1}$.

The purpose of this article is to discuss the downsides of the literary canon in an ex-communist country. In broad lines, I shall resort to a consecrated binary description of canon-making procedures: aesthetic versus ethic, international versus Romanian, the " $80 \mathrm{~s}$ generation versus the millennials. At the same time, I will touch upon the problematic of the didactic canon, but also upon Romanian research in the field of posthumanism, transhumanism, and anateism. The article does not envisage the exhaustive analysis of the Romanian literary canon and its detailed coordinates. The aim is to trace the faults of the present process of canonization especially in those countries still haunted by the ghost of the communist centralized economy. By suggesting the implementation of an inter- and trans-disciplinary canon, I figure a way out of the labyrinth of a propagandistic and possibly distorted culture. Such a pattern is recognizable in every country where the state lavishly sponsors the mainstream culture and where a cultural free-market is impossible because the lack of a genuine competition among authors/artists.

I argue that the old type of canon, relying heavily on the best-promoted works and authors in a certain field - with the literary canon in the limelight - should be replaced with a super-arch-canon. The new canon would assume from the old one the canonization using axiological assessments and the canonicity, but otherwise it would be interdisciplinary and transdisciplinary, diminishing thus those biased valuations and promotions specific to the cultural and scientific fields when these are funded as isolated realms. In the post-industrial and technologized society, the need for a canon that could list assets from various scientific and artistic fields in parallel is manifest and stimulating. This all-encompassing chart of excellency will not cancel the specialized canons. It is similar to a certain degree to what comparative literature enacts by extracting local creations and by placing them into a larger hermeneutic context.

\footnotetext{
1 "Fără să ne propunem o epuizare a resurselor simbolice ale modelului figurat al oglinzii, ni se pare semnificativă oprirea la Narcis, primul celebru fascinat de oglindirea propriului chip, deoarece mitul său face obiectul unei simbolistici deosebit de longevive, însă nu mai puţin procesuale. Fundamentat de antichitate mai degrabă sub specia figurilor tragice, tînărul pedepsit de Nemesis pentru trufia de a-şi fi suficient şi de a fi refuzat dragostea, deci relaţia, va deveni în timp, succesiv, o figură a autoreflexivităţii şi, în cele din urmă a ostentaţiei amendate”. (Mihaela Ursa. Optzecismul şi promisiunile postmodernismului, 1999: 39)
} 


\section{The quarrel of the aesthetics' supporters with the ethics-and- cultural-studies' supporters}

Broadly speaking, the most representative theorists oscillated between two extremes with rare situations of equilibrium and authentic interest in the selection of values. Ideologized approaches have always permeated canonicity showing that the aesthetic approach can also be biased. Even those who explicitly accuse canonization of biases do not seem to be interested in identifying firm axiological criteria, but to stigmatize the concept of the canon itself. John Guillory, for instance, considers that every canon is "infested" with ideologies and socio-cultural determinants (Guillory, 1993: 85). In Harold Bloom's view, every canon, even the counter-canon, is a form of elite gathering (Bloom, 1994: 37). However, this fact induces an agentive dominance that accompanies the processes of selection. Adjacently, imagining a canon of authors, not of contributions, implies a further form of competition. However, authors are not constant generators of masterpieces.

In spite of the risk, many international approaches to canon considered only the literary phenomenon. Thus, Damrosh (2003: 14) identified a central hypercanon and many counter-canons around it. Sell spoke about "many different canons and many different readerships" (2011: 1) and when he referred to postmodernism he viewed it as the most democratic approach checked by the cultural reality too. The democratic canon would be also a product of the dynamics of an economic system. Obviously, this is a Marxian implementation, taken further to a party-bound level by Lenin and Lukács. In fact, it is true that in those countries wherein the official culture is profusely financed by the state, the canon reflects the tastes and preferences of those cultural actors with accrued financial power. In addition, this is quite the contrary to Theodor Adorno's more elevated theory on art as a negative apperception of the world, a later reflection of Keats's romantic negative capability.

More radical is Franco Moretti who, in "The Slaughterhouse of Literature" (2000: 209), backed up the Reader-Response Criticism and diminished the role of professors in configuring canons. In his view, "distant reading" should dethrone classical hermeneutics of close reading, because non-academic readers are more perspicacious than their counterpart is. Examples in point are Conan Doyle, "socially super-canonical right away, but academically canonical only a hundred years later. And the same happened to Cervantes, Defoe, Austen, Balzac, Tolstoy..." (209).

One example that the discussion of canons is far from being a literati's job is that even Nicholas Sarkozy, while running for presidency, questioned the utility of studying the classics for the future workers in industry and administration. This is indicative of the risk of fencing the process of selecting values and containing it inside the circle of isolated groups of 
specialists. That is why E. Dean Kolbas's recommendation of creating instruments able to regulate the process of canonicity should be still in place: "any critique or analysis of the canon must also include a metacritique of the claims that are made about it, an assessment of the social and material conditions of their own possibility" (Kolbas: 140).

\section{The canon as a club with secret access code}

Disregarding the constant checking of the conditions influencing the production of the canon can simply transform it into a coercive and corrupting enterprise. Of course, literary canons will remain as if, as $\mathrm{V}$. Nemoianu put it (V. Nemoianu and Royal, 1991: 217), but this als ob must regard only the guiding purpose of the canon, not its substance. This would mainly coincide with Charles Altieri's bi-functionality of the canon: the "curatorial" function and the "normative" one (in van Halberg, 1984: 41-57). Nevertheless, Altieri also underlined the dark side of the canonizers who use the canons as "ideological banners for social groups" (53-54). Consequently, Altieri took position under the flag of those theoreticians who saw canons as weapons to use against institutional mechanisms and interests, not at all a buttress to authoritarianism, as the title of Frank Kermode's essay, "The Institutional Control of Interpretation", ominously suggests. In his turn, Stanley Fish had no illusions when it came to working in a team with the purpose of selecting values: "it is interpretive communities, rather than either the text or the reader, that produce meanings and are responsible for the emergence of formal features" (Fish, 1980: 14). One essential characteristic of canonicity would be in Frank Kermode's view the debate-open nature of those works included in the canon. They should stir constant interpretation (Kermode, 1988: 127). Jan Gorak synthesized Kermode's requirements for a canonizable work: "it is hospitable to interpretation; it has sufficient depth to support the multitude of interpretations it attracts; and [...] it becomes charged with mystery as time passes" (Gorak, 1991: 153).

Contrary to these requisites came The School of Knowingness, as Richard Rorty baptized Harold Bloom's School of Resentment. "Knowingness" in this case would be a concept that aims at replacing aesthetic credentials with blunt theorizations from the realm of social sciences. Marxian thinkers have always striven to counterbalance the importance of form in aesthetics with a hyperbolized content. Nevertheless, many of them admitted (because honest enough) that art relies mainly on form - if it is to remain art and not a blunt instrument of propaganda (in Rorty, 1997: 125-140).

The median stage of the canonical debate was largely aesthetic, whereas the beginning was "cacofonic" (nobody being in the mood to listen to others) (Takaki, 2002: 137) and the present is a Postcanonical one, in 
which only classical writers accumulate more canonical capital (Damrosch in Saussy, 2006: 44-46). In an aesthetic vein, Damrosch suggested the replacement of the old canonical dyad (major authors - minor authors) with a triadic hierarchy: the hypercanon (the classics), the countercanon (the "subaltern" or contesting voices), and the "canon in the shadow" (old "minor" writers unsuccessfully shortlisted for canonization by various deconstructivist orientations). Damrosch eventually came with an integrative perspective, according to which hypercanonical and countercanonical works should be grouped together for the students' benefit.

François Cusset perceived some similarities between syllabus classicization and religious proselytism: "the canonization of works brings us back both to the historical role of cultural legitimation belonging to educational institutions and, in a more proselytizing sense, to the evangelizing mission that this role of consecration implies [...] Composing the canon is a practice of exclusion, a way to shut out ideas and unfamiliar forms considered as threats to the established order, and it has been that way since the second century $\mathrm{BC}$, when the Romans officially, though unsuccessfully, prohibited Greek works and ideas in Roman schools" (Cusset, 2008: 167-168).

Braving the same connection with the Holy Scriptures, Mike Fleming underlined that the curricular canon revives the original meanings of the concept of canon: "”rule", "norm", "law" (in Sâmihăian, 2010: 11).

The Big Canon - as the container of the best-promoted works and authors - becomes a verdict, a commandment protracted by curriculum legislators. The most often invoked criterion is the representativeness of a certain writer, which can very well translate in terms of the social visibility of that literary actor. Grapes of adaptive torsion?

\section{Canonicity in the Romanian culture}

In the Romanian culture, there were three main contexts of canonization, three literary and cultural groupings: the pro-German and proclassicist Junimea, the modernist Sburătorul, and the postmodernist Cenaclul de Luni. The last one benefited from a plurality of theorizations owing to the fact that many of its members graduated from the Faculty of Philology in Bucharest.

Canonicity re-emerged as a stimulating debate in Romanian culture soon after the fall of the communist regime. By culture I mean especially literature, as this cultural practice has traditionally been the most appealing to the Romanian intellectual environment.

Concerns regarding interdisciplinarity and cross-disciplinarity are of a lesser importance to the Romanian canonizing paradigm. As Mircea Martin 
remarked, the canon can coagulate (integrating the exception), but it can also differentiate (promoting the exception) (in Parpală, 2008: 10).

On the Romanian cultural battlefield, there has always been the confrontation between "revisionist pluralism" and "conservative autonomism", that is, the ethic-defenders accused the aesthetic-defenders of immorality or amorality, whereas the latter suspected the former of narrowmindedness and sheer lack of talent. On the other hand, this is the profound reality in all countries deprived of/uninterested in a genuine cultural market, or lacking in the vital communication between creators and public; namely, the canonical war is waged with budgetary funds. The best-promoted Romanian authors sell poorly in comparison to the funds invested in their public image (Țupa, 2019). When state or supra-state budgets take the forehand, critics who are obviously interested parts in the game foreground values. This seems to verify Alexandru Muşina's view on Romanian postmodernism as one "at the gates of the Orient" (Muşina, 2011: 115), or as a "socialist postmodernism" (110).

Within the frame of the aesthetic canon, there are two arch-theories: one supporting the idea of serial canonizations-decanonizationsrecanonizations, the other one stating that only one canon can subsist in each interval. Parpală-Afana shares a Hegelian view upon projecting the canon, in three steps: canonization, de-canonization or re-canonization (2008: 181). All these are coordinated by meta-canonic reflections.

In Romania, we can identify only one canonizing circle, the aestheticliterary one. It contains other concentric circles, but only the mainstream one will get lavish stipends from the state, so the competing canons are doomed. That is why so many writers who will never have access to those prizes which could make their works canonizable, irrespective of their value, tend to worship the Adonises of the system. They succumb to the condition of worshippers as a legitimizing consolation. The same names have been rotated to all the festivals and prizes, even if the creativity of the writers in discussion has dwindled and their public would be close to very small digits unless their books are promoted with budgetary funds. Other maneuver is to insert some writers in the school syllabus and co-interest the headmasters and teachers to acquire the specific titles for the school library or to recommend them firmly to their students. Very interesting writers like Sorina Delaskela, Diana Iepure, Valentin Nicolau, Chris Tănăsescu, Nicolae Dan Fruntelată, for instance, are hardly visible, not to say promoted by the Romanian cultural institutions.

The complex relationship between canonicity and canonization, as theorized by E. Dean Kolbas $(2001,134)$, is opulently show-roomed in the Romanian culture. An intellectual faction supports the aesthetic flag (without any ethic involvements), another one marches under the colors of ethicism. 
The quarrel cools down when somebody resorts to the intuition to put under the microscope some intellectuals' resistance to communism. All of a sudden, both parties agree that such approach would not be relevant. Apart from Paul Goma and a few other writers belonging to Aktionsgruppe Banat, very few writers manifested an authentic dissidence to the communist party. In this respect, Paul Cernat glosses on "a moral-ideological Procrustean approach" (Cernat, 2010)

\section{Two literary generations in pole positions: the $80 \mathrm{~s}$ and the Millennials}

One of the most lucid minds of the 80s generation was Alexandru Muşina. He took the liberty to quench the self-admiration of his peers. He remarked that the self-praised Romanian postmodernism was no more than a "socialist postmodernism" (Muşina, 2001: 110) and that irrespective of the local enthusiasm it was about "the postmodernism at the gates of the Orient" (115). That is why he undermined the generational canon from the inside by proposing an "existential" project, namely "noul anthropocentrism" (the new anthropocentrism).

Alexandru Muşina was a self-exiled of the same ' 80 s generation. In 1996, he published Paradigma poeziei moderne (The Paradigm of Modern Poetry) and in 1997 Eseu asupra poeziei moderne (Essay on Modern Poetry), where he accused the coryphaei of the ' 80 s generation of communism and of Balkanism in concocting a generational network very effective in praising each other and in hunting key positions in the cultural Establishment (Muşina, 2001: 126-127).

Contemporary with these debates, the millennial writers in Romania made their debut with an obdurate contestation of the postmodern canon in Romania as the communist authorities had also adopted it. Their reaction to canonicity was a healthy one. In The Second Tiuk Manifesto. KLU Literature (Al doilea manifest Tiuk. Literatura KLU), Alexandru Vakulovski, pleaded for a de-structuration of the canonical texts "monumentalized" in schoolbooks: "In order to save literature, the urgent, total disappearance of mandatory literary texts from institutions is needed. [...] We have to react in the right way to the aggression of programs and official literary canon: to recognize true literature wherever it may be" (Vakulovski, 2002, in Parpală, 2008: 181).

Meanwhile, Harold Bloom's seminal study, The Western Canon: the Books and School of Ages, was translated into Romanian in 1998. Five years later, a bilingual anthology on this topic was published (Marin Mincu, Ion Bălu, and Leo Butnaru - Canon şi canonizare/ Canon and Canon-Making, transl.mine, Pontica Press). Their stances are quite related.Before these, in an article from 1997, "For a speedy ending of the aesthetic canon", Sorin 
Alexandrescu highlighted the "methodological retardation of Romanian criticism" (in Parpală, 2008: 183).

The meta-literary component is salient in Mircea Cărtărescu's doctoral thesis, The Romanian Postmodernism (Postmodernismul românesc), 1999. Not only did the best-promoted Romanian writer come with a monolithic and authoritative view on the canon, but he also fetishized his own poetics, to the disgrace of some of his own generation peers (Muşina, Andriescu). When theorization upon canonicity is the achievement of the active actors in the game, results can be slippery. For instance, Cărtărescu believed that the counter-canon of the 80s defended "realists" and "biographic realism", whereas Muşina hailed "the poetry of everyday life" (184). Both were in favor of sincerity, hedonism, simplified stylistics and colloquialism. Being under the same hat, Ioan Buduca proclaimed a "revolution of the subject" in the essay "Banda lui Möbius" ("Möbius's Tape"), 1984. This hailed the replacement of the impersonality of modernist poetry. The strip is a "symbolic metaphor designating indeterminacy, continuity, and interference" (Parpală, 2008: 184) and indeed it indicates the intricacies of communist postmodernism. Confessional poetry, the ethos of a real biography, and an authentic communion with the readers had already been claimed by the American poetry of the 50s and 60s and by the Beat generation. The titles of some of the Romanian postmodernists are encouraging: Cărtărescu, Totul (Everything), 1985, Romulus Bucur, Literatură, viaţă (Literature, Life), 1989, Bogdan Ghiu, the poem "Relaţia dintre noi" ("The relationship between us"), 1989. Actually, their poems are more about "textistence" (texistenţă); they are artificial and coded, as Cărtărescu defined his own concept:

The standard-poem of the eighties tends to be long, narrative, agglutinated, with an orality well marked by special rhetorical effects, aggressive (features specific to the Beat generation); but also ironical and self-ironical, imaginative to the point of onirism, playful, displaying an uncommon prosodic dexterity, finally impregnated with scholarly cultural allusions inserted by metatextual and selfreferential devices (Cărtărescu, 1999: 154 - translation by Emilia Parpală).

The transitive poetry of the $80 \mathrm{~s}$, as Gheorghe Crăciun saw it (Crăciun, 2002: 254) was closer to the "semiotic" than to the "real". Only Muşina strove to check the concept of transitivity by demanding a transfer from "their stylistic intensity to the intensity of communication" (Muşina, 1999: 170). The assumed models for the Romanian poetic postmodernism were Allen Ginsberg, Lawrence Ferlinghetti, Gregory Corso, the confessional poetry of Robert Lowell, and Frank O'Hara's Personism. 
It is interesting that the pinnacle of this generation, Mircea Cărtărescu, rejected the "great literature", "too big, suffocating in its own fat" (in Parpală, 2008: 188), but he has been practicing it for so many years now:
"and poetry? I feel like the last Mohican
Ridiculous like Denver the dinosaur
The best poetry is the bearable poetry
Nothing else: just bearable
We made good poetry for ten years
Without knowing what bad poetry we were making.
We made grand literature, and now we understand
That it cannot go through the door, precisely because it's big,
Too big, suffocated in its own fat
This poem is not really a poem either
For only what is not poetry
Can endure as poetry
Only what is not poetry"2
(Cărtărescu, Occidentul/The West, 2007. Translated by Cristina Hanganu-Bresch, in Parpală, 2008: 188).

Another coryphaeus of the ' $80 \mathrm{~s}$ generation, Gheorghe Crăciun, in his much-acclaimed book Aisbergul poeziei moderne (The Iceberg of Modern Poetry) (2002: 114-115), took distance from Hugo Friedrich and praised the transitive poetry, extracting its sap from everyday life, banality, commonalities, and objective existence. This is what the poets of this generation would have liked to achieve, but they hit the target only theoretically. Otherwise, they did not get too far away from the paradigm inflected by Friedrich (reflexivity, metaphisics, visionarism, purism, and dehumanization). Actually, the arrow aimed at neomodernists hit their own generation, as the distance between their theorizations and their creations is blatant. The much-claimed embrace of reality was rather wishful thinking than sheer fact. Consequently, their art changed formulae but remained elitist and permeated by cultural references. The dream of being communicative, of relying on the phatic function of language did not become reality and their discourse further needed literary initiation. Twenty years later, Adrian Urmanov wrote the manifesto of "Utilitarism" (Utilitarianism) and pasted it on street posts in Bucharest.

\footnotetext{
2 "iar poezia? Mã simt ca ultimul mohican/ ridicol asemenei dinozaurului Denver./ poezia cea mai bunã e poezia suportabilã,/ nimic altceva: doar suportabilã./ noi am fãcut zece ani poezie bunã/ fãrã sã ştim ce poezie proastã am fãcut./ am fãcut literaturã mare, şi acum înţelegem/ cã ea nu poate trece de prag, tocmai fiindcã e mare,/ prea mare, sufocatã de grãsimea ei./ nici poemu-ãsta nu-i poezie/ cãci doar ce nu e poezie/ mai poate rezista ca poezie/ doar ce nu poate fi poezie"
} 
Actually, G. Bacovia, a subtle and intelligent writer, had landed the prosaic poeticity on the Romanian soil. His artistic means were drastically essentialized so that many critics were deceived and described his manner as monochord or simplistic. Later on, Mircea Ivănescu resumed Bacovia's approach and mixed it with American poetic strategies after WWII, but the force of suggestion did not reach the Bacovian level. Marin Sorescu also strove for the "vitalism" of poetry in the cycle "La Lilieci" using a peasantlike discursivity. Both Ivănescu and Sorescu belonged to one generation before the $80 \mathrm{~s}$, whereas Bacovia's creative period spanned five decades (1910-1950).

In Valoare şi canon sau despre sinuciderea din grădina estetică a literaturii române (Value and Canon or about the Suicide in the Aesthetic Garden of Romanian Literature, transl. mine, 2001), Gheorghe Crăciun ventured the term "canon-tabular" (tabular-canon). He tried with this to play down the prevalence of aestheticism in configuring the canon, but he did not envisage an arch-canon. Instead, he summoned north-American ideas about the de-structuring of hierarchies, the uplifting of social, contextual and ideological implications, the reception expectations and so on. Again, many aspects relate to sociology and the new political correctness. In this respect, Crăciun was the regular EU-values defender and surfed the trendiest wave. At most, his vision of the canon remained a warlike one, not in the least collaborative and improvable: "canonul e o hidră cu multe capete, unele adormite, altele (niciodată acelaşi) aflate în acţiune" ("the canon is a manyheaded hydra, some heads slumbering, others (never the same) very active", transl. mine)

Romanian writers strove to stay synchronized with the European canonical paradigm and they "translated" French poststructuralism into Romanian textualism by moving the world into texts and not vice versa. As the poet and book-reviewer Romulus Bucur remarked, the postmodernism of the eighties practiced the "self-canonization" (2000: 198). In fact, the generation was heterogeneous and only its intimate core members were accommodated into the canon. However, two of the best promoted writers of the 80s generation spoke about the pluri-centrality of Romanian postmodernism and described two canonical blueprints. Mircea Cărtărescu (1999: 99, 145, 372) identified a bidirectional poetics, a two-cell nucleus (a "realist"/ "biographical" poetics of contingency, and a "textualist" poetics) and other two marginal directions ("minimalism and neo-expressionism"). Ioan B. Lefter (apud Parpală, 2008: 189) listed three sub-canons: the prosaics, the conceptualists, and the moralists. As we notice, these groupings are not so much selective as they are distributive, with didactic applications. Describing these categorizations, Parpală Afana considers that the "biographic prosaism" would imply the emergence of the referential and 
phatic function of poetry (189). "The 'real' of the ' $80 \mathrm{~s}$ is not the reality as such but a semiotized referent, hostile or indifferent to human acts. Metatransitivity is often accompanied by a rhetoric of referentiality" (23-24).

The poets of the Millennium drastically cut down on the quantity of aestheticism from their new type of authenticity: "while the textualists of the eighties based their semiotic discourse on dialogism and polyphony, the young post-postmodern poets bring forth the corporeality, the contingency and the communication with the reader" (Parpală, 2008: 192). If postmodernists condescended to kitsch, post-communist literati felt entitled to take the experiment further and to catch up with the censured slangy and erotic language of the vanguardist currents of the first half of the $20^{\text {th }}$ century. "The isomorphism between poetry and media discourse" (ibidem) was a step further from the aesthetic canon and benefited a literature that had gravitated tiresomely around excessive stylistics and literary narcissism for almost five decades of communism.

Parpală Afana also describes a post-postmodern counter-canon populated by the generation of the Millennium: "a poetry of crisis, assertive in avant-garde style, isomorphous with the socio-cultural paradigm and paradoxically centred on the thesis of poetry as a communication act" (190). I would not rely so much on the synchronization of the whole production of this generation with the post-postmodern paradigm. Actually, millennials contested the entextualization of the ' $80 \mathrm{~s}$ and ' $90 \mathrm{~s}$ generations and plunged deeply into the outskirts of cities and into their own cenesthesia. These had been spaces unexplored programmatically until then in Romanian poetry, so it was an impending inner synchronization. This "nihilistic radicalism" (190) asked indeed for a new type of authenticity in which the way of living should get closer to the manner of writing. The "exorcising of obscenity, the visceralising of autobiography" (190) were only an ingredient in a heterogeneous mixture. Elena Vlădăreanu, a representative poet of the Millennium generation, emphasized also the rhetoric of otherness, which meant a gap between poetic generations, but her arguments betrayed a generational rhetoric (Vlădăreanu, 2004: 327). It is not about an open otherness, but about a limited shared one, the otherness of a club accessible only to writers with a common Weltanschauung. History repeats, generations strive for the power to canonize their own production.

The evolution of these two generations has been tortuous and revelatory in the end: many representatives of the postmodernist generation of the ' $80 \mathrm{~s}$ who complained that the communist regime deprived them of a surrounding postmodernity plunged into the cultural social after the 1989 Revolution. Millennials started by accusing the ' 80 s generation of lack of authenticity and by promoting a synergy of life and literature, but ended up themselves as solid pillars of the Establishment and quite attached to a 
cultural vision upon the canon, in trend with whatever new criteria of representativeness may shore up.

\section{Aesthetics or cultural political correctness?}

Without denying the significance of the canon, Adrian Dinu Rachieru contested however the utility of a "canonical" literary history in a culture obsessed with lists" (Rachieru, 2009: 10). The arrow targets a certain aesthetic forgery incumbent to a literary world irrigated by funds sourcing from state treasury and not from a viable market. As it were, Romanian literature persists in a communist-like system, which is very suspicious of liberalization.

There were voices who changed the angle and said the canon is a "fraudulent import" in this culture which has been oscillating between Occident and Orient for three centuries. Such an approach inevitably leads to the replacement of the national canon with a generational one.

Again, defending the aesthetic stance, Rachieru enunciated three invariables in the construction of the canon: 1). the canon should be a collective accomplishment, not the dictate of a certain literary critic; 2). the canon has national varieties; 3 ). the fundament of the canon is aesthetic (11). As we can see, this understanding of the canon is restrictive and looks like an inheritor of Harold Bloom's vision (frequently quoted). On the other hand, Rachieru conceded that a culture might benefit of the myths surrounding it. This means that the canon can be used, as any other form of art, to promote an imagological kit. It would be hard to deny the marketable efficiency of the canon, but it would be also hard to take an oath on the honesty and lucidity of the canon-makers.

One of the most academic-established books to defend the aesthetic canon in Romanian culture was Adrian Marino's Hermeneutica ideii de literatură (The Hermeneutics of the Idea of Literature, my translation) from 1987. Right at the start, Marino offered Indications for the Method, in a Cartesian spirit. In his view, there exists a correct method for interpreting and understanding literary texts, an Auslegungkunst (11). However, unaccustomed to the multi-party system as Romania was - because the communist regime dissolved other parties, the competition as it were -, the cultural atmosphere after the Revolution was imbued with ideological bias, almost like there existed a leftist and a rightist approach to the canon. The leftists contest the aestheticism in isolation alongside the Marxist considerations, whereas the rightists support the aesthetic criteria by themselves. Among these two groupings are the moderate leftists who plead in favor of a canon of the minorities; they are also called the pluricanonicals (Nicolae, 2006: 100). 
After the anti-communist revolution from 1989, intellectuals split into two camps: on the one hand, the ones who defended the New Criticism stance - isolation from the political and social context; on the other hand, the ones who shared the New Historicist approach, namely the canon could not get back its authenticity without exposing the political and historical compromises or the agenda of many writers during communism and even post-communism. Virgil Nemoianu ardently pleaded for the theoretical synchronization of the Romanian cultural context. This may have sounded optimistic, but it was not more than the reiterative obsession of many Romanian theoreticians of getting rid of Mihai Eminescu, their national poet (the article "Despărţirea de Eminescu"/ "Goodbye Eminescu"). The new reasons for this expurgation were not aesthetic, but social and ideological (conservatism, past-oriented views, political incorrectness).

In the 1990s, there blew a wind of pluralism and deconstructionist rhetoric, but the means of analysis were the classical aesthetic-modernist ones. In this conservative way, many ideological exaggerations were avoided, at least. Even the collective efforts of some young writers to dismember the myth of the Romanian national poet (M. Eminescu) ended up in a sort of selfmythologizing complaint.

The intellectuals gathered around the progressive cultural journal Observator cultural contested the aesthetic canon but only to replace it with a canon founded this time on the categories of the political correctness in vogue after 1990s. In their opinion, the literary canon should be a reflection of such issues: gender equality, positive discrimination, minorities' rights and so on and so forth. The retarded Romanian postmodernist canon had not had the slightest idea about a cultural canon with another center than literature. Theirs was a paradoxical stance: literature should remain in the limelight, but its appraisal should be done with new instruments, not with authentic literary (read aesthetic) tools.

On the other hand, it came just normal to the former Soviet-andSovietized area to hold in high esteem the aesthetic autonomy after so many decades of blunt and gross scientific materialism and of stultifying ideological imprint. It must be admitted, nonetheless, that because of the successive waves of Stalinism - the latter-day ones being also nationalist many intellectuals emerged from communist regimes with an unquenched desire to be absorbed into an Occidental empire (already politically correct) as a guarantee to their freedom.

\section{What about a nice and clean didactic canon?}

A canonizing ideology tends to boost the didactic canon against the aesthetic canon. This new canon would impersonate capitalist traits: communicability, efficiency, pragmatism, shallowness. Such would be the 
contemporaneous counter-canon. The didactic canon would necessitate refurbished teachers, imbibed with courses of pedagogy to the detriment of their own specialties.

The didactic canon absorbs samples of literary writings in relation to the diversity of their discourse, not necessarily to their aesthetic qualities. On October 31, 2000, "Observator cultural" sheltered a debate on the postcommunist curriculum ("Programe deschise, elastice" - "Open, flexible syllabi", transl. mine) stressing the importance of training competences and abilities, not contents, while studying literary texts in high school. The new keyword was "discourse", replacing the old king "masterpiece". The abilities to communicate and to come with personal points of view popped up in vogue.

In La décanonisation et les manuels (alternatifs) de littérature roumaine, Elisabeta Roşca remarked that between 1990 and 1993 the historical study of literature was given up in favor of a multiplied approach, from cultural to axiological (Roşca, 1998: 288). The new perspective was less aesthetic-obsessed and capable of looking around to the adjacent mentalities and social tastes wherefrom the works of art sprang. Fictional and aesthetic literature was finally placed in the same entourage with frontiertexts: para-literary and non-fictional. The vertical approach to literature was replaced by a horizontal one. This quasi-democratization made many texts within the canon more palatable, as what mattered was not their aesthetic backbone any longer. the Cultural Establishment - those in power and those in opposition together -, convened upon a series of unbeatable authors, while others may be in favor or in disfavor of one of the parties. Inescapably, the core of the literary canon is gilded and praised. Meanwhile, there have been uninterrupted quarrels between those who supported alternative school books, varying in content, and those who defended an official hardline of truth to teach in schools. Postmodernists/ globalists/ relativists against high modernists/ localists/ essentialists. Irrespective of the "alternativity" of schoolbooks, almost everybody concedes to the idea that some truths are more valid than others are.

\section{Posthumanism, anateism, and transhumanism in Romanian theorizations}

The futility of both approaches discussed above is proved by the latest developments in literary and cultural experiments, debated upon in Romania almost concomitantly with the debates abroad. Aesthetics and science come along nicely in the healthy environment of people sincerely preoccupied with knowledge, not with rankings.

Robert Cincu (in Vatra, no. 3-4/2017, pp. 82-86) contended that posthumanism did not open a completely new paradigm; it only marked a 
chronological stage after the demise of postmodernism and postmodernity. He sagaciously underlined that posthumanism is not identical with the antihumanism, transhumanism, or cyberpunk. Nevertheless, he embraced the views of Luca Valera ("Posthumanism. Beyond Humanism?", in Cuadrenos de Bioetica, XXV, 2014/, pp. 481-491) and Rosi Braidotti (The Posthuman, 2013) regarding the separation of transhumanism (which exalts the technological enhancement of humanity) from posthumanism (which deplores the alienation provoked by technology). Many researchers perceive transhumanism as the dystopian side of posthumanism, circumscribing it to an all-encompassing paradigm. However, Cincu himself produced a remark that absorbs him into the larger theorizing contingent; namely, he admitted that the transhumanist utopia is the posthumanist dystopia. In the end, the supporters of the two smaller and opposed trends arrived at the conclusion that posthumanism is in fact a neo-humanism.

Another category subsumed to posthumanism would be the anateism, an -ism that heralded the revival of the human and of God, after Nietzsche and Foucault had announced their respective deaths. A further split distinguishes between a soft and a hardcore posthumanism. Robert Cincu exemplifies the former with the analysis made by Slavoj Žižek (in How to Read Lacan) on comedy series. Here, the phenomenon of canned laughter indicates the fact that machines not only did subvert human labour (in modernity), but they finally replaced human feelings. This is a type of subtle robotization. The hardcore perspective has as points of reference movies as Terminator (where a cyborg longs to become human - which is a posthuman hint), and Star Wars (where transhumanism and anateism are synthesized in Darth Vader, a character who is both cyborg and devotee of an ancient religion, worshipping the Force).

Vasile Mihalache took side with the super-paradigm that would include more Posthumanisms. He was able to identify the roots of the new philosophy in the theorizing of the "masters of suspicion" (Nietzsche, Freud, and Marx), as Paul Ricoeur calls them in De l'Interprétation: Essai sur Freud.

Posthumanism would be indebted to the negative criticism practised by anti-humanism. However, posthumanism is descriptive and affirmative, as it aims at establishing a new series of concepts and a new ethics, appropriate for the contemporary world (see Donna Haraway, "A Cyborg Manifesto", or McKenzie Wark, "Information wants to be free (but is everywhere in chains)"

Curiously enough, Vasile Mihalache told posthumanism from transhumanism when he contended that the latter remained, paradoxically, encapsulated in the humanist ideology. That means that the Cartesian duality mind/body persists in the technology-obsessed world and is corroborated with the idea that human consciousness could be transferred to a machine. 
Continuing to mix theoretical stances, Vasile Mihalache described cyborgs/gamers/hackers as heroes of posthumanism, heroes without a stable ontology. The posthuman identity stays fluid and multiple (Haraway, The Promises of Monsters: A Regenerative Politics for Inappropriate/d Others, 1992; Hayles, How We Became Posthuman). For posthumans, consciousness would be only an entity that was granted exaggerated powers by the linguistic turn.

\section{Conclusions: what if they are siblings?}

In a country wherein official culture is profusely sponsored by the state even after the fall of communism, we cannot shy away from the possibility that institutionalized culture dictates the canon without negotiation. Only those who are willing to conjure the goodwill of critics and officials have a good chance to be brought up to light. In this way, the mainstream canon mirrors not only the aesthetic or heteronomic realities, but also all the inequities of a society at a given moment.

Across this article, I pinpointed the contingency of the piecing together the canon as various researchers expressed it. The translation is: you are on friendly terms with the gallerists, your work will be exhibited and the public will visualize it; otherwise, irrespective of its intrinsic qualities, it will vanish. This is the reason for which I turned myself towards a more comprehensive and less socially empowered canon. The super-arch-canon, by putting in parallel values selected from various fields, becomes a second selection in itself, a bird's eye view canon that reveals weird non-synchronicities and disparities. An overall quality measurement is possible as everything is a form of creation. It is simply futile to overprize the literary canon.

We should study the problems of canonization and of canonicity from a specific angle in the ex-communist countries. One may find in this area inferiority complexes and a hysteric volition of synchronicity with the West translated into prize hunting. Especially in the case of Romania, there is a huge frustration because of not having secured a Nobel Prize for literature until now. The implied risk is to get into a situation of all hat and no cattle, idiomatically speaking. This is the reason for the smooth cooperation between those who defend an aesthetic-founded canon and those who reclaim ethic clarifications or a canon built in accordance with the standards propounded by cultural studies and the correspondent political correctness; or the final agreement between the ' $80 \mathrm{~s}$ generation and the millennials, after initial accusations of inauthenticity on the part of the latter. Convulsions have been registered on the configuration of the didactic canon, as schoolbooks are preeminent in consecrating representative writers. In this state-budgeted, monopolized and quite provincial cultural context, the only dynamic debates around canonicity are those revolving around posthumanism, transhumanism, 
and anateism. An interdisciplinary and transdisciplinary super-arch-canon, paralleled by a liberalized cultural market are the only democratic solutions for transforming the Romanian culture into a less parochial one.

\section{References:}

Altieri, C. "An Idea and Ideal of a Literary Canon", in Halberg van, Robert (ed.) (1984). Canons, USA: The University of Chicago Press. pp. 41-57.

Bucur, R. (2000). Poeţi optzecişti (şi nu numai) in anii '90/ Poets of the '80s (and not only) during the '90s. Pitești: Paralela 45.

Cărtărescu, M. (1999). Postmodernismul românesc/ The Romanian Postmodernism. București: Humanitas.

Crăciun, Gh. (2002). Aisbergul poeziei modern/ The Iceberg of the Romanian Poetry. Piteşti: Paralela 45.

Cusset, F. (2008). French Theory. How Foucault, Derrida, Deleuze \& Co. Transformed the Intellectual Life of the United States. Minneapolis: University of Minnesota Press.

Damrosh, D. (2003). What is World Literature? Princeton: Princeton University Press.

Fish, S. (1980). Is There a Text in This Class? The Authority of Interpretive Communities. Harvard University Press.

Gorak, J. (1991). The Making of the Modern Canon. Genesis and Crisis as a Literary Idea. London \& Atlantic Highlands: The Athlone Press Ltd.

Guillory, J. (1993). Cultural Capital. The Problem of Literary Canon Formation. Chicago and London: The University of Chicago Press.

Kermode, F. (1988). History and Value. "Canon and Period", 117-135. Oxford University Press. https: //doi.org/10.5040/9781472554390.ch-005

Kernan, A. (1990). The Death of Literature. New Haven: Yale University Press.

Kolbas, E. (2001). Critical Theory and The Literary Canon. University Westview Press, USA. https: //doi.org/10.4324/9780429501197

Moretti, F. (2000). "The Slaughterhouse of Literature", Modern Language Quarterly, volume 61, no. 1.

Muşina, A. (1999). Poezia cotidianuluil The Poetry of the Every Day Life. In Gh. Crăciun. 1999, 165-168.

Muşina, A. (2001). Sinapse, „Postmodernismul socialist”/ "The Socialist Postmodernism”. Braşov: Editura Aula.

Nemoianu, V. and Royal, R. (eds.) (1991). The Hospitable Canon: Essays on literary Play, Scholarly Choice, and Popular Pressures. Philadelphia/Amsterdam: John Benjamins Publishing Company.

Nicolae, C. (2006). Canon, canonic. Mutaţii valorice în literatura americană contemporană/ Canon, canonic. Value changes in Contemporary American Literature. București: Editura Univers Enciclopedic.

Parpală, E. (2009). "Alternative Canons. Postmodern Canon-formation in Romanian Poetry", in Romanian Poetic Postmodernism. 1980-2010. A Semio-Pragmatic 
and Cognitive Approach. Research supported by CNCSIS - UEFISCSU project PNII - IDEI, number 757/19.01.2009: Code: 381 /2008.

Rachieru, A.D. (2009). „Mihai Eminescu şi canonul literar românesc”/ „Mihai Eminescu and the Romanian Literary Canon", Metaliteratură, an IX, nr. 5-6 (22).

Rorty, R. (1997). "On the Inspirational Value of Great Works of Literature", in Achieving Our Country: Leftist Thought in Twentieth-Century America. (The William E. Massey Sr. Lectures in the History of American Civilization). Harvard University Press.

Roşca, E. (1997-1998). «La décanonisation et les manuels (alternatifs) de littérature roumaine»/ "The decanonization and the alternative textbooks of Romanian literature", Euresis. Changement de canon culturel chez nous et ailleurs/ Euresis. Change of Cultural Canon at Us and Everywhere, Bucarest: Univers, pp. 286-290.

Sâmihăian, F. (coord.) (2010). The Literary Canon. Approaches to Teaching Literature in Different Contexts,. București: Editura Universităţii din Bucureşti.

Saussy, H. (ed.) (2006). Comparative Literature in an Age of Globalization. Baltimore: The John Hopkins University Press. $\underline{\text { htps: }}$ //doi.org/10.1086/651517

Sell, R.D. (2011). Communicational Criticism. Studies in literature as dialogue. Amsterdam/ Philadelphia: John Benjamins Publishing Company.

Takaki, R. (ed.) (2002). Debating Diversity: Clashing Perspectives on Race and Ethnicity in America. Oxford University Press; $3^{\text {rd }}$ edition.

Ursa, M. (1999). Optzecismul şi promisiunile postmodernismului/ The ' $80 \mathrm{~s}$ Generation and the Promises of Postmodernism. Piteşti: Paralela 45.

Vlădăreanu, E. (2004). "Ia-ţi târfa şi pleacă"/ "Get yor whore and leave" - Marin Mincu. Generaţia 2000 (Cenaclul Euridice). Antologiel Generation 2000 (Euridice Literary Circle). An Anthology. Constanţa: Pontica. pp. 325-328.

\section{Links}

Ţupa, R. (2019) “Cele mai vândute cărţi”/"The Best Sold Books", https://www. mediafax.ro/life-inedit/cele-mai-vandute-carti-bookfest-intre-nemultumiri-sielogii-la-adresa-editiei-2019-18153858; accessed 10 April 2020.

Cernat, P. (2010) "Iluziile revizionismului est-etic (II)"/"The Illusions of the East-Ethic Revisionism", https: //www.observatorcultural.ro/articol/iluziile-revizionismuluiest-etic-ii/; accessed 13 April 2020. 